\title{
Sustainable Scotland: putting environmental justice at the heart of the policy agenda?
}

\author{
E. McDowell ${ }^{1} \&$ C. McWilliams ${ }^{2}$ \\ ${ }^{1}$ Glasgow Caledonian University, Scotland \\ ${ }^{2}$ Heriot Watt University, Scotland
}

\begin{abstract}
The Scottish Executive has declared its intention to 'put environmental concerns at the heart of public policy and secure environmental justice for all communities'. By way of secondary analysis, we explore two high-profile community campaigns which convey a fundamental tension between the rhetoric and practice of environmental justice within an urban framework. A number of concerns from local communities suggest that the proclaimed enthusiasm for sustainability conceals the true cost of its implementation at a local level. We are of the view that environmental justice - flaunted as a core policy government commitment - throws up a range of contradictions and misconceptions, which implies the need for a more progressive and inclusive approach to the implementation of policy.

Keywords: city, sustainable development, environmental justice, Scottish Executive.
\end{abstract}

\section{Introduction}

The question of who pays and who benefits from current industrial and development policies is central to any analysis of environmental justice. Despite improvements in environmental protection over the past several decades, many people continue to live in unsafe and unhealthy physical environments. Numerous economically impoverished communities and their inhabitants are exposed to greater health hazards in their homes, their jobs and in their neighbourhoods when compared to their more affluent counterparts (Bullard [1]; Adeola [2]). The most polluted urban communities are those with crumbling infrastructure, ongoing economic disinvestment, deteriorating housing, 
inadequate schools, chronic unemployment, a high level of poverty and an overloaded health-care system. Incinerators and other polluting facilities tend to be cited in low-income, disempowered neighbourhoods. The ideal site, according to some analysts has nothing to do with environmental soundness but everything to do with lack of social power (Walker et al. [3]).

In this section that follows, we aim to summarise evidence of environmental inequalities and injustice within a Scottish context - highlighting in particular, the case of the Greengairs community, which has suffered the worst aspects of the planning system for decades. Following this we will consider an ongoing and highly controversial campaign involving the extension of the M74 six-lane motorway through the south side of the city of Glasgow.

\section{Environmental justice: the early days}

According to Warner [4] as recently as thirty years ago the term environmental justice was unknown. However, since then it has become something of a rallying cry for community groups, the focus of academic research and an orientating principle for public bodies. Bulkleley and Walker [5] state the concept of environmental justice came to prominence through the growth and development of the environmental justice movement in the US, where in the late 1970s increasing evidence indicated that racial minorities and low-income groups bore a disproportionate burden of environmental risks. The link between social justice and environmental issues was clearly made by communities objecting to the siting of toxic chemical plants, land-fills and waste incinerators close to their homes (McWilliams and Walton [6]). The movement for environmental justice grew as a reaction to the limitations of mainstream environmentalism, which was viewed as being dominated by elitist 'white upper-class environmental' individuals and reflected their narrow range of views. Further, many argued (e.g. Bullard [1]) that the traditional environmental movement was not adequately addressing issues such as race, power and inequality. Environmental justice can be regarded as a heterogeneous movement as it seeks incorporate anti-racist, feminist and anti-corporate and post-colonial politics. Overall, the movement has sought to include the most marginal and excluded groups in society, those least able to defend themselves or articulate their thoughts against more powerful private sector companies or state institutions.

While it might be a policy area whose time has come, within the UK the gaps in comprehensive analysis are substantial (Walker et al. [3]). In addition to this, Agyeman [7] maintains that the terms 'environmental' and 'justice' do not easily sit together. This is supported in other quarters, such as the Institute for Public Policy Research [8] who suggest that despite the synergies between sustainable development and social justice it is peculiar to find a lack of political awareness regarding the parallels between the environmental justice movement and theories of social justice. However, we echo the views of Dobson [9] who argues that the concepts of justice and sustainability are not so divergent that cannot be brought together, particularly if policies of sustainability have distributive consequences 
and justice is essentially about distributing benefits and burdens in the political community (Miller [10]; Lucash [11]).

\section{The Scottish Executive: a commitment to environmental justice?}

'Too often the environment is dismissed as a concern of those who are not confronted with bread and butter issues. But the reality is the people who have the most urgent environmental concerns in Scotland are those who cope daily with the consequences of a poor quality of life, and live in a rotten environment, close to industrial pollution, plagued by vehicle emissions, streets filled with litter and walls covered in graffiti. This is true for Scotland and also true elsewhere in the world. These are circumstances which would not be acceptable to better off communities in our society, and those who have to endure such environments in which to bring up a family, or grow old themselves are being denied environmental justice'.

Speech by First Minister, Jack McConnell at ERM environment lecture, Edinburgh $18^{\text {th }}$ February, 2002 [12].

With the establishment of the Scottish Parliament on $1^{\text {st }}$ July 1999 the opportunity to deal with issues 'close to home' became a reality within a Scottish context. It is also notable that Jack McConnell's (First Minister for Scotland) inaugural policy speech was on environmental justice. Maintaining this message, the Scottish Executive proudly announce that 'the benefit to the environment is best delivered by strong communities' with a Government committed to the philosophy of 'connect and involve' (Scottish Executive [13]). Although activists and green politicians welcomed such official recognition of environmental justice, they also emphasise that much more needs to be done to rectify the situation and that addressing the unjust environmental impact that developed countries such as Scotland place on people in other parts of the world and on future generations is a critical challenge to the delivery of sustainable development (Dunion [14]). In this sense the struggle for environmental justice is not just local but increasingly global.

The crucial links between the environment and health have also be acknowledged by the Scottish Executive: If we improve life circumstances, improve our air quality and water quality, if we reduce noise pollution and ensure healthy living, then our health service itself becomes more sustainable and the quality of life in Scotland is enjoyed for longer (McConnell [12]). Within the context of environmental justice, alternatives to using a car have also been stressed. Thus, a focus on using public transport and an improvement in these services (bearing in mind the large numbers of people from less affluent areas who do not own cars) has been a key component of government discourse. Finally, as part of the commitment made to the Aarhus convention, the Scottish Executive requests that its public institutions should take the lead in providing more information to the public; development plans must have a suitable 
timeframe; and the public should be encouraged to participate in relevant debates. As the Scottish Executive acknowledges:

local people often better understand than anyone else, the pressures on their area and their contribution to the actions and choices made by public bodies is invaluable (Ross Finnie [15]).

Despite the growing government rhetoric, general policy initiatives often fail to accommodate local specificities. Over the past decade there has been a significant rise in evidence correlating to the proximity of environmental degradation with an individuals/groups social class, ethnic status and geographical location (Walker et al. [3]). In terms of the big 'three Es' environment, economy and equity - central to a sustainable society, equity has been the poor relation and least represented in policy debates. In this context, the evidence to date points more towards acts of environmental injustices rather than environmental justice.

\section{Environmental justice in Scotland: unpacking the evidence}

Over the past decade, there has been a substantial rise in evidence correlating the disproportionate proximity of environmental degradation with deprived communities (FoE Scotland [16]; Scandrett et al. [17]; Dunion [14]; Agyeman and Evans [18]; Fairnburn et al. [19]; Hastings et al. [20]). Scotland has a long history of industrial and urban development and subsequent pollution (Adams [21]). Studies demonstrate the directing of hazardous developments to 'toxic sacrifice zones' - where dirty industries are enticed, simply because the community has lived with it for decades and where there is least resistance (McDowell and Chalmers [22]). A recent study by researchers at Glasgow University, established a significant gap between the environmental amenity of deprived and less deprived neighborhoods, which was reflected in service standards and 'unintended biases' in resource allocation Hastings et al, [20]. However, further research is necessary to establish exactly why this inverse relationship in services for deprived areas is taking place.

Many deprived areas in Scotland (and the rest of the UK) reveal the highest levels of pollutant concentrations (Walker et al. [3]). Other more recent studies (Hastings et al. [20]) show that people living in the most deprived areas, overwhelmingly but not exclusively urban Scotland, experience by far the worst environments - not just in terms of pollution, but with respect to more general problems of litter, derelict sites, graffiti; gaps in amenity and services, often in more densely populated areas, with higher levels of high-rise buildings and undefended open space (Hastings et al. [20]). Evidence also suggests that deprived communities bear the brunt of dangerous factory pollutants (emissions to air of chemicals recognized as being carcinogenic). It is significant that the highest percentage of industrial factories are located predominantly in more deprived local authority areas resulting in the higher levels of pollution in these areas (Walker et al. [3]; Warner [4]).

Agyeman and Evans [18] note that Scottish communities located in the worst environments are more likely to be those with least power, mainly caused by 
their poverty, unemployment, isolation or more likely a combination of these. The growing recognition and attempts to address environmental injustices has led to the emergence and adoption of an environmental justice agenda. For example, environmental justice has been adopted by Friends of the Earth Scotland, to provide an alternative discourse to sustainable development, which emphasizes commitment to the struggle of communities who suffer most environmental damage. Dunion [14] outlined a present day definition of environmental justice in Scotland as follows:

- People perceive environmental injustice when authorities fail to afford or uphold rights.

- Where people are unable to adequately participate in the decisionmaking processes that affect them and where the means of redress are inaccessible.

- In particular environmental injustice is experienced as a result of practices, or policies which, intentionally or unintentionally, disparately impact on the living conditions of low - income groups.

Prior to devolution, many Scottish people felt disenfranchised from a centrally controlled government in Westminster. Ironically, there is now evidence of a renewed sense of disenfranchisement towards a centrally controlled agenda based in Edinburgh. Sustainable development is (or at least should be) a challenge to the traditional model of governance, based on the assumption that policy elites located in central government have the capacity to prescribe standard solutions across diverse localities. However, if anything, devolution appears to have developed a tendency to prescribe policy and impose standard solutions that have few bearings on the distinct needs of communities (McDowell [23]).

Conflict may be regarded as an indicator of underlying unsustainable social, economic, and environmental relations in society, as they are manifest in a particular community. Yet, it is incongruous that the people who challenge environmental justice issues are often viewed by officials as 'trouble-makers' (Dunion [14]). The way in which communities relate to conflict, their interpretation of it, the extent to which it mobilizes the community and leads to knowledge demands, has a strong bearing on how well communities move to a more critical, just and sustainable form of development.

\section{Greengairs: a community mobilized for action}

'A lack of voting and financial powers to make any changes for ourselves mean we bear a disproportionate burden of the waste for the whole of Scotland'. (Anne Coleman, Greengairs campaigner).

Located in the coal rich region of the Central Belt of Scotland, Greengairs is a traditional working class community in North Lanarkshire, Scotland, with typically low involvement in the process of decision-making. Local communities in the Greengairs suffered harsh social and economic consequences from the 
closure of most of the deep mines in the UK coalfields in the 1980s and 1990s. However, further indignities were to follow, with the expansion of open-cast mining, which generated few employment opportunities and significant environmental harm due to the heavy machines and goods vehicles, dynamite blasting and associated liberation of dust into the atmosphere. Once worked out, open-cast mines are required to be reinstated and one of the ways in which this can be achieved is by using them for landfill. In the Greengairs area there are now nine landfill sites and open cast mines. Clearly, the noise and visual (local eye-sore) pollution, vibration, unwanted smell and dust emanating from the landfill and open cast mines militate against the Scottish Executive's goal of promoting environmental justice for all communities. In addition to this soil contaminated with polychlorinated biphenyls (PCBs) was brought to one of the Greengairs landfill sites from Hertfordshire (England), because contamination levels were higher than would be permitted anywhere nearer. FoES released the information and the community mobilized to blockade the site. Following several days of action, senior management (Shanks and McEwan the landfill operator) met with the community and agreed to a number of concessions including an end to the toxic dumping; an independent inspection of the landfill site; and improvements to its safety.

By 2002 in part recognition of the serious environmental impact which the open-cast and landfill sites were having in and around Greengairs, Scotland's First Minister pledged that there would be no more landfill sites in the area. However, in 2004 planning permission was granted for the creation of a new landfill, in the face of local objection. Local residents and pressure groups claim that the First Minister has reneged on his pledge to protect the local environment. The case of Greengairs is not alone in illustrating a failure of implementing a sustainable development agenda through the contemporary Scottish planning system. The absence of 'third-party right of appeal' against planning decisions is viewed as major weakness of the planning system in Scotland. Public agencies and developers can appeal against decisions, but residents of Greengairs could not directly challenge the permission for the latest landfill site in 2004. Environmentalists, such as FoES have consistently called for a 'third-party right of appeal', for local communities to object to unwanted developments. However, these calls have already been rejected by the Scottish Executive. Instead, Ministers have said local people would be involved in the planning process, on a consultation basis only, at an earlier stage than previously (BBC News [24]). Many claim this is a missed opportunity to genuinely allow for the voice of the people to be heard and to give power to local communities.

\section{The M74 extension: a road too far?}

'There is much to support the view in Hickman's forensically damming analysis the policy in support of environmental justice would be breached by the proposed road. The impact on the communities would be very severe because they would be divided, polluted and assaulted by noise'.

Chairman of JAM 74 (anti-road campaign) cited in Edwards [25]. 
The Scottish Executive was recently taken to task by a powerful coalition of 26 environmental groups - the 'Everyone Campaign' who acknowledged that while the First Minister, Jack McConnell had shown a personal commitment to sustainable development also stress that 'his current enthusiasm for economic growth could be forcing Scotland in the wrong direction' (Edwards [25]). The proposed M74 motorway extension in Glasgow has raised serious doubts about the Executive's pledge to environmental justice. Despite a lengthy public enquiry, stressing the "potentially devastating effects on the local and wider community, which would be at variance with policies to include social inclusion and environmental justice' - the five mile, $£ 500 \mathrm{~m}$ extension was given the go ahead by Scottish Executive Ministers (Edwards [25]). The rejection of the independent Hickman inquiry by Ministers contradicts the Executive's commitment to reducing road traffic, encouraging public transport and cutting climate change pollution (the focus of the G8 summit hosted in Gleneagles, Scotland in July 2005).

\section{Rethinking environmental justice: the policy challenge}

New ways need to be found that include rather than exclude. A more inclusive progressive sustainability agenda must make all citizens, especially the most marginalised, integral to policy making. Decision making will need to become more transparent, inclusory and participatory. Government needs to move away from what Harvey [26] calls 'after-the-event' action towards more pre-emptive or proactive interventions to address environmental injustices. Concerns for environmental justice are still too subservient to concerns for economic efficiency, economic growth and capital accumulation. Harvey [26] also argues that the dominant view of government with respect to the environment is the 'standard view of environmental management'. This anthropocentric position involves the pursuit of profit and development at the expense of the environment. Thus, rather than preventing environmental damage from happening in the first place, problems are considered when they arise, which suggests a denial of the irreversibility of some environmental damage (Harvey [26]). However, that is not to suggest there is no contestation. The case of Greengairs and the proposed M74 motorway extension demonstrates the need to put inequalities at the top of the environmental agenda will directly challenge the dominant discourses (be they of sustainable development or ecological modernization variety). Is the Scottish Executive willing to do just that? As Harvey [26] argues 'there is a long and arduous road to travel to take environmental justice movement beyond the phase of rhetorical flourishes, media successes and symbolic politics into a world of strong coherent political organizing and practical action'. Environmental justice requires policies which treat people equitably. Arguably, without environmental justice there can be no sustainable development. The challenge is for the Scottish Executive to move from sustainability rhetoric to sustainable just policies. 


\section{Conclusion}

This paper argues that environmental problems are vested disproportionately upon the poor. The examples given of Greengairs and the M74 extension demonstrate this fact. In addition, while the policy agenda in the UK (and Scotland the focus of this paper) appears to be shifting in the direction of promoting an environmental justice agenda it is, in our view, in its early infancy. While there is an obvious theoretical commitment (evident in government rhetoric) much has to be done in practice. It is noteworthy that the First Minister in Scotland has shown that the Executive can go its own way with respect to selected devolved issues, for example, taking a decisive lead to ban smoking in public places, due to come into effect on $26^{\text {th }}$ March 2005 . Why not with environmental justice? The challenge is to develop and pursue public policies that do not disproportionately disadvantage any particular social group over another. This will require a re-engagement with questions of social and environmental justice and whether existing policies produce a fair and defendable distribution of benefits and burdens in society.

\section{References}

[1] Bullard, R., Confronting Environmental Racism: Voices from the Grassroots, Boston: South End Press, 1994.

[2] Adeola, F., Environmental hazards, health and racial inequity in hazardous waste distribution, Environment and Behaviour, 26, pp. 99-126, 2002

[3] Walker, G; Fairburn, J, Smith, G and Mitchell, G., Environmental Quality and Social Deprivation, Environmental Agency: London, 2003.

[4] Warner, K., Local sustainability initiatives with environmental justice, Local Environment, 7, pp. 35-47, 2002.

[5] Bulkleley, H. and Walker, G., Environmental justice: a new agenda for the UK, Local Environment, 10 (4), pp. 329, 2005.

[6] McWilliams, $\mathrm{C}$ and Walton, J., Environmental rights and justice, (chapter 6). The Essential of Human Rights, eds. R.K.M Smith and C, van den Anker, Hodder Arnold: Oxford University Press, pp. 122-125, 2005.

[7] Agyman, J., Constructing environmental (in)justice: transatlantic tales, Environmental Politics, 11, pp. 31-53, 2002.

[8] IPPR., Sustainability and Social Justice. IPPR: London, 2004.

[9] Dobson, A., Fairness and Futurity: Essay's on Environmental Sustainability and Social Justice, Oxford University Press, 2004.

[10] Miller, D., Social Justice, Oxford: Claredon Press, 1976.

[11] Lucash, F., Justice and Equality Here and Now, NY: Cornell University Press, 1986.

[12] McConnell, J., Environmental Justice http://www.scotland.gov.uk/ News/ NewsExtras/57.

[13] Scottish Executive., Down to Earth: A Scottish Perspective on Sustainable Development, Scottish Executive: Edinburgh, 1999. 
[14] Dunion, K., Troublemaker: The Struggle for Environmental Justice in Scotland, Edinburgh: Edinburgh University Press, 2003.

[15] Scottish Executive, A Partnership for a Better Scotland, Scottish Executive: Edinburgh, 2003.

[16] FoES, The Campaign for Environmental Justice: Thinking of Scotland's Environment. FoE Scotland, 1999.

[17] Scandrett, E, Dunion, K and McBride, G., The campaign for environmental justice in Scotland, Local Environment, 5 (4), pp. $467-$ 474, 2000.

[18] Agyeman, J. and Evans, B., 'Just sustainability': the emerging discourse of environmental justice in Britain? The Geographical Journal, 170 (2), p 155, 2004.

[19] Fairburn, J. Walker, G and Smith, G., Investigating Environmental Justice in Scotland: Links between measures of environmental quality and social deprivation, 2005.

[20] Hastings, A, Flint, J, McKenzie, C and Mills, C., Cleaning Up Neighbourhoods, Environmental Problems and Service Provision in Deprived Areas. Bristol: The Policy Press, 2005.

[21] Adams, I., The Making of Urban Scotland, Croom Helm: Edinburgh, 1978.

[22] McDowell, E and Chalmers, D., Sustainable development in Scotland: responses from the grassroots, (Chapter 5) in Environment Scotland: Prospects for Sustainability, eds. McDowell. E and McCormick. J., Ashgate Publishers, pp.80-99, 1999.

[23] McDowell, E., Sustainable development at the periphery: responding to problems of socio-economic marginalisation, in the sustainable city, ed. Marchettini et al, WIT Press, UK, pp. 431-441, 2004.

[24] BBC http://news.bbc.co.uk/1/hi/scotland/4544058.stm.

[25] Edwards, R., The Sunday Herald Tuesday 15th December, 2005.

[26] Harvey, D., Justice, Nature \& the Geography of Difference, Oxford: Blackwell Publishers Ltd, 1996. 